\title{
Makten i uklare formuleringer
}

Eric Arthur Blair (1903-50), bedre kjent under pseudonymet George Orwell, ble for alvor berømt for romanene Animal farm (1945) og 1984 (1949). De ble skrevet helt på slutten av hans liv (Orwell døde av tuberkulose 46 år gammel) og var visstnok de eneste han tjente noe særlig på. Disse bøkene reflekterer hans livslange redsel for og mistro til autoritære styresett - uansett politisk farge. Ikke minst i romanen 1984 innførte og definerte han begreper og uttrykk - f.eks. «storebror ser deg» - som senere har gått inn i standardvokabularet når totalitære regimer, invaderende byråkratier, maktarroganse og propaganda diskuteres og analyseres.

I sin samtid var imidlertid ikke Orwell mest kjent som romanforfatter, men som journalist, kommentator og essayist $i$ aviser og tidsskrifter og som forfatter av reportasje- og fagbøker. Han var meget opptatt av viktigheten av et presist og klart språk (fagspråk, ikke skjønnlitteratur) og av konsekvensen av det motsatte: Hvordan et forenklet og upresist språk kan misbrukes av makthavere. I essayet Politics and the English language (1) fra 1946 angriper han upresis språkbruk og særlig det han kalte «politisk prosa». Orwell mente at formålet med slik språkføring var å skjule sannheten, og at språket var bevisst vagt og meningsfattig. Han så en klar sammenheng mellom språklig manipulering og undertrykkende ideologier. Disse tankene utviklet han videre i 1984, der makthavernes «nytale», som skulle gjøre det umulig å tenke avvikende tanker, sto sentralt.

Om kvelden 26. august satt jeg og lyttet til foredragene og debatten på Oslo legeforenings temamøte «Oslo Universitetssykehus - blir tilbudet bedre, verre eller status quo?». Jeg hadde store problemer med å henge med på foredragene til Jan Eirik Thoresen og Øystein Dolva (for tiden henholdsvis viseadministrerende direktør og fagdirektør ved Oslo universitetssykehus). Det var ikke fordi innholdet var intellektuelt krevende, men fordi det som sto på de pent designede Powerpoint-bildene var både selvfølgelig og diffust på samme tid. Hva betydde det? Hadde de nå en klar plan, eller skulle det fortsatt «tygges»? Var konsekvensutredninger og risikovurderinger nå på plass for dette - for pasientene - svære eksperimentet?

I pausen før debatten var galgenhumor det som preget de fremmøtte legene, men alvoret lå ikke langt under overflaten. Jeg hørte det jeg har hørt så skremmende mange ganger de siste årene: At mange gode fagfolk har gitt opp («Her blir det mye førtidspensjonering»), enten helt eller ved bare å konsentrere seg om de nære ting (pasientene og kollegene). Det gjelder å holde seg fast til stormen - $\mathrm{i}$ dette tilfellet omorganiseringen - har lagt seg. Endring er sjelden populært blant ansatte, og helsepersonell er intet unntak, men når det ser ut som om mange høykompetente medarbeidere vil abdisere, burde varsellampene for lengst ha blinket rødt.

Debatten etterpå var ikke mindre urovekkende. Det ble stilt helt betimelige og konkrete spørsmål av typen: «Hvor skal ambulansene kjøre hardt skadede pasienter hvis multitraumesenteret skal flyttes sist, mens alle spesialistene som trengs for å betjene det, har flyttet tidligere?» «Hvordan skal Oslo ta hånd om den forventede befolkningsøkningen, ikke minst av gamle, når så mange sengeplasser legges ned (les: Aker sykehus)?» «Omorganiseringen gjør det nesten umulig å få gjennomført studentundervisning, hva skal vi gjøre?»
Svarene var gjennomgående av typen «Vi vet det blir utfordringer, men dem skal vi klare sammen med dere!», «Ja, vi står foran krevende prosesser». Hva skal man si til slikt? Det ble spurt om hva slags evaluering det var lagt opp til både underveis og til slutt i prosessen. Svaret på det var at evaluering var umulig, dessverre. Hvorfor det? På enkelte punkter presset spørsmålsstillerne litt hardere på og ble møtt med tradisjonelle hersketeknikker (Thoresen): «Tror du jeg hadde drevet med dette hvis jeg ikke hadde tro på det og syntes det var moro?«

Tonen i debatten var høflig, om enn resignert, med unntak av et par verbale kraftsalver helt mot slutten fra bl.a. Kjell Maartmann-Moe, fastlege i Oslo, og Steinar Solberg, karkirurg ved Rikshospitalet nei, unnskyld - karkirurg ved Oslo universitetssykehus HF, Hjerte-, lunge og karklinikken, Thoraxkirurgisk avdeling, Rikshospitalet, Postboks 4950 Nydalen, 0424 Oslo, som den korrekte (og visstnok mye enklere) adressen vil være fra 13.9. 2010.

Etter møtet satt jeg igjen med flere spørsmål enn svar og med en sterk følelse av å ha sovet $\mathrm{i}$ timen. Hva er egentlig begrunnelsen for denne gigantomleggingen? Hva vil de oppnå? Det finnes ingen forskning som viser at sammenslåing av sykehus gir bedre kvalitet på tjenestene eller noen målbar økonomisk gevinst $(2,3)$. En av dem som har forsket mest på dette i Norge, Lars Erik Kjekshus, gikk allerede i 2002 tydelig ut og sa dette i forbindelse med at daværende Helse Øst ønsket å slå sammen sykehus. Daværende viseadministrerende direktør Bente Mikkelsen sa den gang at det selvsagt var frustrerende at man ikke hadde skikkelig kunnskap å bygge på. I sin rapport til styret skrev likevel Helse Øst at «... tiltakene vil redusere behovet for nyinvesteringer og på lengre sikt gi økonomisk gevinst». Nå er det ikke lenger økonomisk gevinst som er begrunnelsen.

Jan Eirik Thoresen forsøkte på møtet 26. august å begrunne sammenslåingen ved å vise frem et bilde av de mange datasystemene som er i bruk ved Oslo-sykehusene og understreket at det ikke nyttet å få til god samhandling når disse systemene ikke kommuniserte med hverandre. Det er selvsagt beklagelig og uforståelig at sykehusene i 2010 ikke har klart å få på plass gode nok datasystemer. Men løsningen på det er å utvikle dem - man trenger vel ikke radere ut velfungerende sykehus og avdelinger for å få fornyet datasystemene? Burde man ikke argumentere saklig og ordentlig på empirisk grunnlag - for at dette kan fungere og ikke er direkte farlig for pasientene? Eller er argumentasjonen bevisst uklar? «The great enemy of clear language is insincerity. When there is a gap between one's real and one's declared aims, one turns as it were instinctively to long words and exhausted idioms» (1).

\footnotetext{
Charlotte Haug

redaktør

Litteratur

1. Orwell G. Politics and the English Language. Horizon 1946; 13, nr. 76: 252-65.

2. Kjekshus LE, Hagen TP. Ga sammenslåinger av sykehus høyere effektivitet? Erfaringer fra Norge i 1990-årene. Tidsskrift for Velferdsforskning 2003; 5: 2-13.

3. Brødholt GS. Stordrift uten gevinst. Forskere: Lønner seg ikke å slå sammen sykehus. Dagsavisen 27.9.2002
} 